\title{
Promotive Effects of DCPTA on Seedling Development and Growth of Radish
}

\author{
J.H. Keithly ${ }^{1}$ and H. Yokoyama \\ U.S. Department of Agriculture, Agricultural Research Service, Fruit and Vegetable Chemistry \\ Laboratory, 263 S. Chester Ave., Pasadena, CA 91106 \\ H.W. Gausman \\ Cropping Systems Research Laboratory, Route 3, Box 215, Lubbock TX 79401 \\ Additional index words. bioassay, bioregulator, gene expression, Raphanus sativus, 2-(3,4- \\ dichlorophenoxy) triethylamine
}

\begin{abstract}
A radish (Raphanus sativus L. CV. Scarlet turnip white tipped) seedling growth test was developed to examine promotive effects of 2-(3,4-dichlorophenoxy) triethylamine (DCPTA) on seedling vigor and plant development. Compared with controls, seed treatment using $30 \mu \mathrm{M}$ DCPTA significantly $(P=0.05)$ enhanced the rates of root and hypocotyl elongation and seedling dry weight. Enhanced hypocotyl development by DCPTA showed a significant linear correlation $(r=0.83)$ with the increased taproot yield of mature plants grown from DCPTA-treated seeds. The harvestable taproot yield and harvest index of plants grown from seeds treated with $30 \mu \mathrm{MCPTA}$ were increased $109 \%$ and $38 \%$, respectively, as compared with controls. Incubation of radish seeds in $30 \mu \mathrm{MCPTA}$ with actinomycin-D, alpha-amanitin, amisomycin, or cordycepin significantly reduced DCTPA-mediated seedling growth. These results indicate that nuclear gene expression and translation of mRNA on $80 \mathrm{~S}$ ribosomes are required for the acceleration of seedling development by DCPTA.
\end{abstract}

The tertiary amine bioregulator DCPTA has been shown to increase the vegetative growth and harvestable yield of crop plants (Keithly et al., 1990, 1991a, 1991b). In addition, DCPTA promotes seed germination and increases seedling vigor. The rate of guayule (Parthenium argentatum Gray) seed germination was increased significantly by DCPTA treatment to dry seeds (Hayman and Yokoyama, 1990). Application of DCPTA to ungerminated cotton (Gossypium hirsutum L.) seeds significantly increased the root : shoot ratio of seedling plants (Gausman et al., 1988). In tomato (Lycopersicon esculentum Mill.), DCPTA treatment significantly increased seedling root and hypocotyl elongation growth and increased the relative growth rate of treated plants when compared with controls (Keithly et al., 1991a). In this study, a radish seedling growth test was used to further investigate the correlation of DCPTA-enhanced seedling vigor with improved harvestable yield.

\section{Materials and Methods}

Chemicals. DCPTA was synthesized and purified by the methods of Poling et al. (1977) and Echols et al. (1981), respectively. All other chemicals were purchased from Sigma Chemical Co. (St. Louis).

Seedling growth studies. Radish seeds (cv. Scarlet turnip white tipped) were provided by the Ferry Morse Seed Co., Modesto, Calif. Solutions of DCPTA that ranged in concentration from 3 $\mu \mathrm{M}$ to $50 \mathrm{~mm}(\mathrm{pH} 4.3)$ were prepared using distilled water. All DCPTA solutions contained $0.1 \%$ Tween $80(\mathrm{v} / \mathrm{v})$. Radish seeds were hydrated for $6 \mathrm{~h}$ at $22 \mathrm{C}$ in $0.1 \%$ Tween 80 . Hydrated seeds were then incubated in either $0.1 \%$ Tween 80 (control) or DCPTA solutions at $22 \mathrm{C}$ for $6 \mathrm{~h}$. After treatment, seeds were germinated (95\% germination frequency) in darkness at $27 \pm$

Received for publication 12 June 1991. Accepted for publication 28 Oct. 1991. References to company or product names do not imply approval or recommendation of the products by the U.S. Dept. of Agriculture to the exclusion of others that may be suitable. The cost of publishing this paper was defrayed in part by the payment of page charges. Under postal regulations, this paper therefore must be hereby marked advertisement solely to indicate this fact.

'Corresponding author.
$1 \mathrm{C}$ for $48 \mathrm{~h}$ using a ragdoll seed germination method (Gausman et al., 1988). Each ragdoll contained 60 to 65 seeds, and four replicates were prepared for each DCPTA treatment. After 48 $\mathrm{h}$, primary root and hypocotyl lengths of 50 randomly selected germinates were determined for each replicate. Root tissue was distinguished from hypocotyl tissue by the emergence of root hairs along the primary root axis. Seedling growth experiments were performed five times.

Inhibitor studies. Radish seeds were hydrated as described for seedling growth studies. Seeds were then co-incubated for 6 hat $22 \mathrm{C}$ in $30 \mu \mathrm{M}$ DCPTA and one of the following metabolic inhibitors: actinomycin-D, $4 \mu \mathrm{M}$; alpha-amanitin (AM), $5 \mu \mathrm{M}$; anisomycin, $19 \mu \mathrm{M}$; and cordycepin, $40 \mu \mathrm{M}$. Control seed lots were co-incubated for $6 \mathrm{~h}$ in $0.1 \%$ Tween 80 and inhibitor. For AM pulse studies, seeds were incubated for $6 \mathrm{~h}$ in $0.1 \%$ Tween 80 and then transferred to a solution of $30 \mu \mathrm{M}$ DCPTA. Alphaamanitin $(5 \mu \mathrm{M})$ was added to the DCPTA solution as a pulse treatment; from 0.5 to 1,1 to 2,2 to 3,3 to 4,4 to 5 , or 5 to $6 \mathrm{~h}$ after the DCPTA treatment. After treatment with AM, seeds were rinsed five times in distilled water and reincubated in fresh $30 \mu \mathrm{M}$ DCPTA for a total of a 6-h DCPTA seed treatment. After the AM pulse treatment, seeds were germinated in ragdolls as described for seedling growth studies.

Greenhouse studies. Treated and control seeds were planted in 3.5-liter pots filled with a mixture of 2 fir bark : 2 redwood bark :1 sand :1 sphagnum peat (by volume). Seedlings were thinned to one plant per pot at the two true-leaf stage of development. Greenhouse-grown plants received a photosynthetic photon flux (PPF) of 1200 to $1400 \mu \mathrm{mol} \cdot \mathrm{m}^{-2-} \mathrm{s}^{-1}$ photosynthetically active radiation (PAR). Photoperiod was adjusted to $12 \mathrm{~h}$ with metal halide lamps (PPF at plant height, 450 $\left.\mu \mathrm{mol} \cdot \mathrm{m}^{-2} \mathrm{~s}^{-1} \mathrm{PAR}\right)$. The greenhouse was maintained at a 24 $\pm 4 \mathrm{C} / 16 \pm 2 \mathrm{C}$ day/night cycle. Plants were fertilized weekly with 3 g 20N-27.2P-16.6K/liter. Each treatment group contained 20 replicates and each pot was considered to be an experimental unit. All pots were arranged as a completely randomized block. Foliage treatments of $0.1 \%$ Tween $80(\mathrm{v} / \mathrm{v})$ that contained $30 \mu \mathrm{M}$ DCPTA ( $3 \mathrm{ml}$ solution per plant) were performed at 6, 16, and 23 days after seed planting. Treatments were applied using a trigger-action hand sprayer. 
Plants were separated into root and shoot samples 30 days after seed planting. Taproot diameters were recorded. Total leaf areas were determined using a Delta $\mathrm{T}$ video leaf area meter (Decagon Devices, Pullman, Wash.). Harvest indices were determined from fresh weight and dry weight values, after the plants were dried to constant weights at $75 \mathrm{C}$. Plant growth and yield studies were performed five times.

Lycopene analysis. Cotyledon pairs (1 g fresh weight per sample) were homogenized in acetone using a Polytron. Total carotenoids were extracted into acetone and were saponified (Benedict et al., 1985). Lycopene was quantified by absorption spectrophotometry (Benedict et al., 1985).

Statistical analyses. All growth data were subjected to analysis of variance with linear and quadratic regression analyses (Zar, 1974). Separations among treatment means were also determined using Duncan's multiple range test at $P=0.05$ (Zar, 1974).

\section{Results}

Application of $30 \mu \mathrm{M}(10 \mathrm{ppm})$ DCPTA as a soak treatment to hydrated radish seeds increased the rate of primary root and hypocotyl elongation during seedling development (Fig. 1) when compared with the growth of controls. Radish seeds were fully hydrated after $6 \mathrm{~h}$ of imbibition, and all chemical treatments were performed before radicle emergence. Promotive and inhibitory effects of DCPTA on the development of etiolated radish seedlings were observed (Fig. 2). The largest numerical increases in root and hypocotyl elongation were observed in the $30 \mu \mathrm{M}$ DCPTA-treatment group when compared with controls. Treatments of seed with $>150 \mu \mathrm{M}$ DCPTA inhibited seedling growth. Lycopene accumulation in cotyledons was induced by DCPTA treatments that were inhibitory to seedling growth. Treatments using >3 mm DCPTA (1000 ppm) inhibited seedling growth and lycopene accumulation in cotyledons and resulted in seedling tissue necrosis. The largest numerical improvements in seedling dry weight and root : shoot ratio were observed with $30 \mu \mathrm{M}$ DCPTA when compared with controls (Table 1). However, quadratic responses indicated inhibitory effects of 300 and $900 \mu \mathrm{M}$ DCPTA-treatments on seedling development.

Metabolic inhibitors of transcription and translation effectively prevented seedling growth enhancement by DCPTA (Table 2). Coincubation of radish seeds in $30 \mu \mathrm{M}$ DCPTA with 5

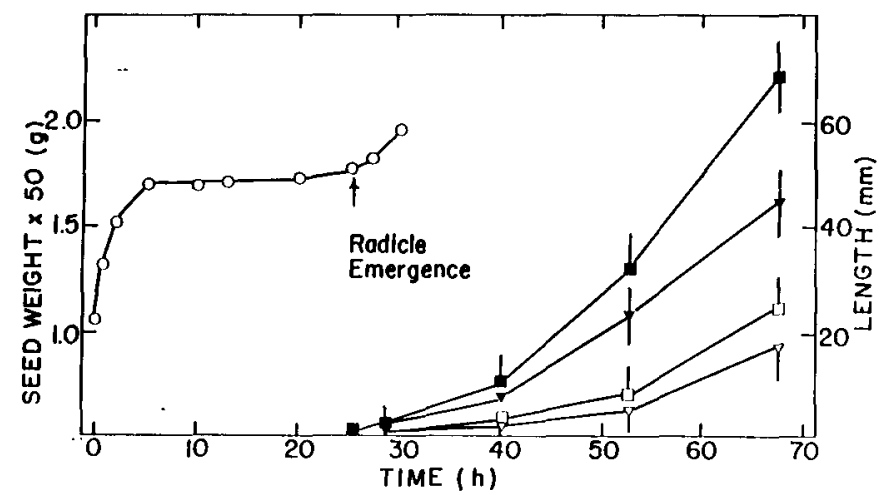

Fig. 1. Enhanced elongation growth of etiolated radish seedlings by DCPTA. Hydration of 50 radish seeds at $22 \mathrm{C}$ shown on left. Hydrated seeds were incubated in $0.1 \%$ Tween 80 (control) or $30 \mu \mathrm{M}$ DCPTA for $6 \mathrm{~h}$ before radicle emergence (hours 6-12). Data represent means $(n=50) \pm S E$. Control root, $\nabla ; 30 \mu \mathrm{M}$ DCPTA root,

$\square$; Control hypocotyl, $\nabla$; $30 \mu \mathrm{M}$ DCPTA hypocotyl, $\square$.

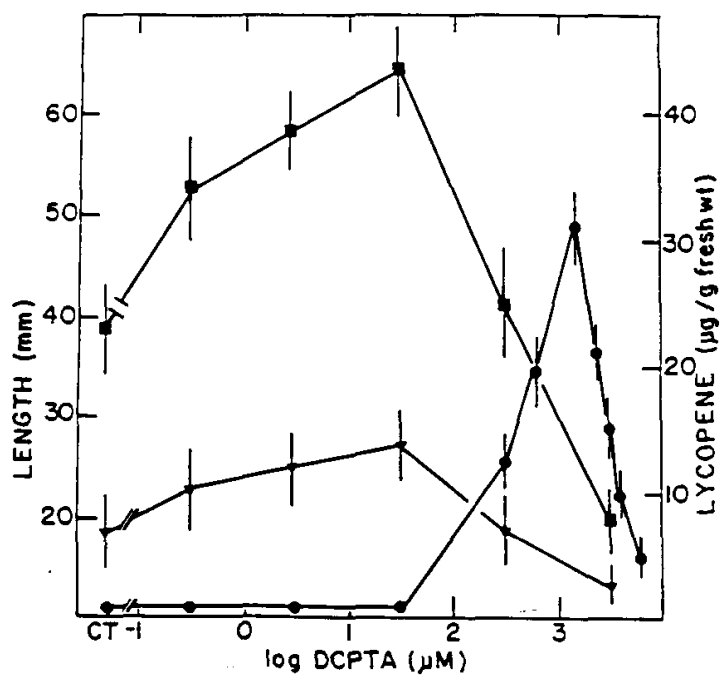

Fig. 2. Concentration dependence of DCPTA-mediated seedling growth and lycopene accumulation by cotyledons. Data represent means (n $=50$ ) \pm SE. Root length, $\square$; hypocotyl length, $\boldsymbol{\nabla}$; cotyledon lycopene, $O$.

Table 1. Enhanced dry weight of etiolated radish seedlings by DCPTA. Shoot values represent the combined weights of hypocotyl and cotyledon tissues. Root : shoot ratios $(\mathrm{R}: \mathrm{S})$ were determined from dry-weight values. Data represent mean $(n=50)$ values from five independent experiments.

\begin{tabular}{lrccc}
\hline \hline \multirow{2}{*}{$\begin{array}{l}\text { DCPTA } \\
(\mu \mathrm{M})\end{array}$} & \multicolumn{3}{c}{ Dry wt $(\mathrm{mg} \times 100)$} \\
\cline { 2 - 4 } & Root & Shoot & Total & $\mathrm{R}: \mathrm{S}$ \\
\hline 0 & 94 & 668 & 758 & 0.141 \\
3 & 98 & 684 & 782 & 0.143 \\
30 & 106 & 732 & 838 & 0.145 \\
300 & 94 & 658 & 752 & 0.143 \\
900 & 72 & 660 & 732 & 0.109 \\
Significance & $\mathrm{Q}^{*}$ & $\mathrm{Q}^{*}$ & $\mathrm{Q}^{*}$ & $\mathrm{Q}^{*}$ \\
\hline
\end{tabular}

*Significant at $P=0.05 ; \mathrm{Q}=$ quadratic.

Table 2. Inhibition of DCPTA-mediated root and hypocotyl elongation. ${ }^{z}$

\begin{tabular}{|c|c|c|c|c|}
\hline \multirow{2}{*}{$\begin{array}{l}\text { DCPTA } \\
(\mu \mathrm{M})\end{array}$} & \multirow[b]{2}{*}{ Inhibitor } & \multirow{2}{*}{$\begin{array}{c}\mu \mathrm{M} \\
(\mathrm{ppm})\end{array}$} & \multicolumn{2}{|c|}{ Length $(\mathrm{mm})$} \\
\hline & & & Root & Hypocotyl \\
\hline 0 & --- & $\cdots$ & $48.3 \mathrm{~b}$ & $17.3 \mathrm{~b}$ \\
\hline 30 & -- & & $77.6 \mathrm{a}$ & $24.8 \mathrm{a}$ \\
\hline 0 & Actinomycin-D & $4(5)$ & $50.9 \mathrm{~b}$ & $15.6 \mathrm{~b}$ \\
\hline 30 & & 4 & $51.3 \mathrm{~b}$ & $17.2 \mathrm{~b}$ \\
\hline 0 & Alpha-amanitin & $5(5)$ & $56.0 \mathrm{~b}$ & $21.0 \mathrm{~b}$ \\
\hline 30 & & 5 & $48.4 \mathrm{~b}$ & $14.6 \mathrm{~b}$ \\
\hline 0 & Anisomycin & $19(5)$ & $53.2 \mathrm{~b}$ & $17.1 \mathrm{~b}$ \\
\hline 30 & & 19 & $54.3 \mathrm{~b}$ & $17.6 \mathrm{~b}$ \\
\hline 0 & Cordycepin & $40(10)$ & $52.3 \mathrm{~b}$ & $17.2 \mathrm{~b}$ \\
\hline 30 & & 40 & $59.3 \mathrm{ab}$ & $18.3 \mathrm{~b}$ \\
\hline
\end{tabular}

${ }^{z}$ Mean separation within columns $(n=50)$ by Duncan's multiple range test, $P=0.05$.

$\mu \mathrm{M}$ AM, $4 \mu \mathrm{M}$ actinomycin-D, $19 \mu \mathrm{M}$ anisomycin, or $40 \mu \mathrm{M}$ cordycepin significantly $(P=0.05)$ inhibited DCPTA-mediated seedling growth without inhibition of controls. Seedling growth enhancement by DCPTA was effectively blocked by $1-\mathrm{h}$ pulses with AM that were applied simultaneously with DCPTA (Fig. 3a). However, significant growth inhibition by AM was not observed when DCPTA was applied $4 \mathrm{~h}$ before ungerminated 


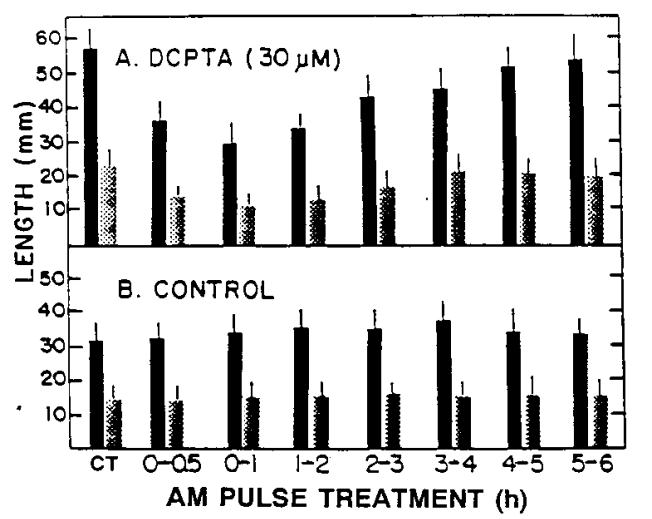

Fig. 3. Inhibition of DCPTA-enhanced seedling growth by $5 \mu \mathrm{M}$ alpha-amanitin (AM) pulse treatments. Data represent means $(\mathrm{n}=$ 50) \pm SE. Root length, solid bars; hypocotyl length, shaded bars.

Table 3. Enhancement of leaf growth and taproot yield of radish by DCPTA. Plants were harvested 30 days after seed planting $(\mathrm{n}=$ 20).

\begin{tabular}{ccccccc}
\hline \hline & \multicolumn{2}{c}{ Leaf } & & \multicolumn{2}{c}{ Root } & \\
\cline { 2 - 3 } $\begin{array}{l}\text { DCPTA } \\
(\mu \mathrm{M})\end{array}$ & $\begin{array}{c}\text { Dry wt } \\
(\mathrm{g})\end{array}$ & $\begin{array}{c}\text { Area } \\
\left(\mathrm{dm}^{2}\right)\end{array}$ & $\begin{array}{c}\text { Dry wt } \\
(\mathrm{g})\end{array}$ & $\begin{array}{c}\text { Diam } \\
(\mathrm{mm})\end{array}$ & $\begin{array}{c}\text { Harvest } \\
\text { index }^{\mathbf{z}}\end{array}$ \\
\hline 0 & 1.1 & 3.7 & & 0.5 & 18.2 & 0.32 \\
3 & 1.1 & 3.7 & & 1.0 & 28.4 & 0.47 \\
15 & 1.6 & 5.2 & & 1.1 & 30.1 & 0.41 \\
30 & 1.4 & 4.8 & & 1.2 & 32.6 & 0.46 \\
150 & 1.1 & 3.6 & & 0.6 & 22.1 & 0.37 \\
Significance & $\mathrm{Q}^{*}$ & $\mathrm{Q}^{*}$ & & $\mathrm{Q}^{* *}$ & $\mathrm{Q}^{* *}$ & $\mathrm{Q}^{*}$ \\
\hline
\end{tabular}

${ }^{\mathrm{z}}$ Harvest index $=\mathrm{g}$ dry weight taproot $/ \mathrm{g}$ total plant dry weight.

*,**Significant at $P=0.05$ or 0.01 , respectively. $\mathrm{Q}=$ quadratic.

seeds were pulsed with AM (Fig. 3a). Control seeds were insensitive to AM that was applied as a short-term pulse treatment (Fig. 3b).

Leaf and taproot development of mature radish plants were increased significantly by the application of DCPTA to hydrated seeds (Table 3). Significant 'quadratic responses were observed for all growth variables that were measured. Compared with controls, leaf and taproot yields of mature plants were improved significantly with 15 and $30 \mu \mathrm{M}$ DCPTA. Taproot development of mature radish plants grown from DCPTA-treated seeds (Table 3) showed a significant positive linear correlation with primary root $(r=0.86)$ and hypocotyl $(r=0.83)$ length (Fig. 1). Taproot development of plants grown from seeds treated with $30 \mu \mathrm{M}$ DCPTA showed the largest numerical improvement when compared with controls.

Seed-treatment application appeared to be the most effective use of DCPTA to increase radish plant growth and yield productivity (Table 4). With increasing plant age (days after seed planting), applications of DCPTA to foliage became progressively less effective in enhancing taproot development. Application of DCPTA at the onset of secondary taproot development (23 days after seed planting) did not improve radish taproot yield.

\section{Discussion}

Seed germination and seedling growth tests are commonly used to screen the biological activities of naturally occurring and synthetic plant growth regulators (Yopp et al., 1986). The results of this study show that DCPTA-enhanced primary root and hypocotyl growth are correlated with improved taproot yield
Table 4. Effect of the time of application of DCPTA on the taproot yield of mature radish plants. Plants were harvested 30 days after seed planting. Letters within columns indicate mean $(n=20)$ separations according to Duncan's multiple range test, $P=0.05$. Harvest indices (HI) based on root and shoot fresh-weight values.

\begin{tabular}{llcccc}
\hline \hline & & & \multicolumn{2}{c}{ Root } & \\
\cline { 4 - 5 } $\begin{array}{l}\text { DCPTA } \\
(\mu \mathrm{M})\end{array}$ & $\begin{array}{c}\text { Type of } \\
\text { application }\end{array}$ & $\begin{array}{c}\text { Time of } \\
\text { application }^{z}\end{array}$ & $\begin{array}{c}\text { Fresh wt } \\
(\mathrm{g})\end{array}$ & $\begin{array}{c}\text { Diam } \\
(\mathrm{mm})\end{array}$ & HI $^{\mathrm{y}}$ \\
\hline 0 & Seed & --- & $18.4 \mathrm{~b}$ & $27.5 \mathrm{~b}$ & $0.54 \mathrm{~b}$ \\
30 & Seed &.-- & $27.7 \mathrm{a}$ & $36.8 \mathrm{a}$ & $0.67 \mathrm{a}$ \\
30 & Foliage & 6 & $23.8 \mathrm{ab}$ & $34.5 \mathrm{a}$ & $0.61 \mathrm{ab}$ \\
30 & Foliage & 16 & $21.3 \mathrm{ab}$ & $31.8 \mathrm{ab}$ & $0.59 \mathrm{~b}$ \\
30 & Foliage & 23 & $17.8 \mathrm{~b}$ & $27.1 \mathrm{~b}$ & $0.62 \mathrm{ab}$ \\
\hline
\end{tabular}

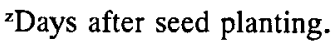

${ }^{\mathrm{y}} \mathrm{HI}=\mathrm{g}$ fresh weight taproot/g total plant fresh weight.

(Table 3; Figs. 1 and 2). The positive correlation between hy$(\mathrm{n}=$ pocotyl growth and taproot yield is important since the taproots of "round" radish cultivars are almost completely formed from hypocotyl tissue (Vreugdenhil and Bouwmeester, 1989). Compared with controls, an enhanced dry-matter maintenance was observed in DCPTA-treated seedlings (Table 1), which suggests an effect of DCPTA on the respiratory efficiency (Bewley and Black, 1983) of germinating seeds. Mature radish plants grown from DCPTA-treated seeds showed significant improvements in total dry weight and harvest indices as compared with controls (Table 3). These results suggest that DCPTA may increase net $\mathrm{CO}_{2}$ fixation per unit leaf area and significantly increase photosynthate partitioning to developing root sinks during plant growth. Previous studies have shown DCPTA treatments to enhance net photosynthesis of mature sugarbeet (Keithly et al., 1990) and spinach (Keithly et al., 1991b) leaves due to improvements in chloroplast compartment size. In addition, competition for photosynthate by root and leaf sinks may increase net $\mathrm{CO}_{2}$ fixation in mature, photosynthate-exporting leaves of DCPTA-treated plants (Keithly et al., 1990, 1991b).

Derepression of DNA-dependent RNA synthesis has been implicated as the mode of action of tertiary amine bioregulators on carotenoid biosynthesis (Benedict et al., 1985; Greenblatt et al., 1986). Our study has shown that inhibitors of transcription and translation effectively inhibit DCPTA-enhanced seedling development (Table 2). Alpha-amanitin and actinomycin-D inhibit nuclear RNA polymerase II activity and mRNA chain elongation, respectively, whereas cordycepin induces premature mRNA chain termination. Anisomycin is an inhibitor of protein synthesis on $80 \mathrm{~S}$ ribosomes. Our study indicates that enhanced radish seedling development by DCPTA depends on de novo nuclear gene expression and translation of mRNA on $80 \mathrm{~S}$ ribosomes. Growth inhibition of DCPTA-treated seedlings by means of pulsing with AM (Fig. 3) suggested that a rapid alteration of nuclear RNA polymerase II activity was induced by DCPTA. The conservation of mRNA and ribosomal RNA during seed maturation (Aspart et al., 1984; Bewley and Black, 1983) would explain the observed insensitivity of control seeds to inhibitor treatments (Table 2; Fig. 3). Our results (Table 2; Figs. 2 and 3) and the results of previous studies (Benedict et al., 1985; Greenblatt et al., 1986) suggest that a common mode of action may regulate vegetative plant growth and carotenoid biosynthesis in tertiary amine-treated crops. Application of DCPTA as a seed-treatment appeared to be the most effective dosage method to increase radish taproot yield (Table 4). These results suggest that plant growth regulation by DCPTA may involve the tem- 
poral control of nuclear gene expression during radish seedling development.

Separate experimental methodologies are generally used to describe the biological activities of tertiary amines on carotenoid biosynthesis (Benedict et al., 1985; Greenblatt et al., 1986) and crop growth (Gausman et al., 1988). However, the results of this study indicate that the radish seedling growth method may be used to examine vegetative growth and carotenoid induction by DCPTA. In addition, the seedling growth test would provide a useful bioassay of the growth-inducing activities of newly synthesized tertiary amine bioregulators.

\section{Literature Cited}

Aspart, L.; Y. Meyer, M. Laroche, and P. Penon. 1984. Developmental regulation of the synthesis of proteins coded by stored mRNA in radish embryos. Plant Physiol. 76:664-673.

Benedict, C. R., C.L. Rosenfield, J.R. Mahan, S. Madhavan, and H. Yokoyama. 1985. The chemical regulation of carotenoid biosynthesis in Citrus. Plant Sci. 41:168-173.

Bewley, J.D. and M. Black. 1983. Physiology and biochemistry of seeds in relation to germination. vol. L Springer-Verlag, Berlin. p. 132-171.

Echols, L. C., V.P. Maier, S.M. Poling, and P.R. Sterling. 1981. New bioregulators of gibberellin biosynthesis in Gibberella fujikuroi. Photochemistry 20:433-437.

Gausman, H. W., H. Yokoyama, J.E. Quisenberry, J.H. Keithly, and J.D. Burd. 1988. Effects of diethylaminoethyl-3,4-dichlorophen- ylether (DCPTA) on cotton (Gosypium hirsutum L.) root/shoot ratio. Bul. Plant Growth Regulat. Sot. Amer. 16:16-17.

Greenblatt, G. A., C.L. Rosenfield, H. Yokoyama, and C.R. Benedict. 1986. The mode of action of 2-(4 -methylphenoxy) -triethylamine (MPTA) on carotenoid biosynthesis in cotton cotyledons. Plant Physiol. (suppl.) 80:66. (Abstr.)

Hayman, E.P. and H. Yokoyama, 1990. Enhanced germination rates and growth of DCPTA-treated guayule seed. HortScience 25:16141615.

Keithly, J. H., H. Yokoyama, and H.W. Gausman. 1990. Effect of $2-$ (3,4-dichlorophenoxy)triethylamine [DCPTA] upon the growth and development of sugarbeet. Plant Sci. 68:57-64.

Keithly, J. H., H. Yokoyama, and H.W. Gausman. 1991a. Enhanced vegetative growth and development of processing tomato by DCPTA treatment of seed. J. Amer. Soc. Hort. Sci. 116:693-696.

Keithly, J. H., H. Yokoyama, and H. W. Gausman. 1991b. Regulation of crop growth and yield by tertiary amine bioregulators, p. 223246. In: H.W. Gausman (cd.). Plant biochemical regulators, Marcel Dekker, New York.

Poling, S. M., W.J. Hsu, and H. Yokoyama. 1977. Structure activity relationships of chemical inducers of carotenoid biosynthesis. Photochemistry 14:1933-1938.

Vreugdenhil, D. and H.J. Bouwmeester. 1989. Effects of ethylene on tuberization in radish (Ruphanus sativus). Plant Growth Regulat. 8:21-30

Yopp, J. H., L.H. Aung, and G.L. Steffens. 1986. Bioassays and other special techniques for plant hormones and plant growth regulators. Plant Growth Regulat. Sot. Amer. p. 156-171.

Zar, J.H. 1974. Biostatistical analysis. Prentice-Hall, Englewood Cliffs, N.J. p. $151-280$. 